\title{
Pelatihan Cara Berpikir Simbolik-Matematik Di Sma Bopkri 2 Yogyakarta
}

\author{
Raden Gunawan Santosa ${ }^{*}$, Junius Karel Tampubolon ${ }^{2}$
}

1,2 Universitas Kristen Duta Wacana

\section{A R T I C L E I N F O}

Article history:

Received 10 December 2019

Received in revised form 01 January 2020

Accepted 30 January 2020

Available online 28

February 2020

\section{Kata Kunci:}

Simbolik-Matematik

ekuivalensi logis , implikasi

logis , pola, kontinu

Keywords:

Symbolic-Mathematical, logical equivalence, logical implications, patterns, continuous

\begin{abstract}
A B S T R A K
Berpikir Simbolik-Matematik adalah teknik berpikir untuk menyelesaikan problem Matematika. Teknik ini merupakan hasil kombinasi Logika Simbolik dan Matematika. Secara umum ada tiga aktivitas logika simbolik yang diaplikasikan pada Matematika yaitu membaca simbol, ekuivalensi logis dan implikasi logis. Pengabdian kepada Masyarakat (PkM) ini mempunyai aktifitas kegiatan untuk pelatihan cara berpikir Simbolik-Matematik dengan menggunakan 15 strategi. Hasil dari pelatihan ini ada tiga hal penting . Hasil yang pertama adalah jenis problem yang paling sulit dihadapi para siswa adalah jenis problem yang memerlukan penarikan kesimpulan yang mengacu pada definisi matematika yang baku. Hal yang kedua adalah untuk jenis penggunaan strategi penyelesaian model pada sebuah sistem dan jenis melihat pola, para siswa cenderung dapat menyelesaikan soal setelah diberi petunjuk bagaimana model yang cocok pada problem serta pola yang dimiliki problem. Sedangkan yang ketiga adalah dari dua kelompok kelas siswa ternyata bahwa kelas yang kontinu mengikuti pelatihan lebih mendapatkan peningkatan kemampuan berpikir simbolik-matematik daripada kelas yang lainnya.
\end{abstract}

\section{A B S T R A C T}

Symbolic-Mathematical Thinking is a technique of thinking to solve mathematical problems. This technique is the result of a combination of Symbolic Logic and Mathematics. In general there are three symbolic logic activities that are applied to Mathematics, namely reading symbols, logical equivalents and logical implications This Pengabdian kepada Masyarakat (PkM) has activities to train SymbolicMathematical thinking using 15 strategies for BOPKRI 2 high school students. The results of this training are three important things. The first result is the type of problem that is most difficult for students to face is the type of problem that requires drawing conclusions that refer to standard mathematical definitions. The second thing is for the type of use of model settlement strategies in a system and the type of seeing patterns, students tend to be able to solve problems after being given instructions on how the model fits the problem and the pattern the problem has. Whereas the third is from two groups of students the class turns out that the continuous class attending the training gets more symbolic-mathematical thinking skills improvement than the other classes.

\footnotetext{
* Corresponding author.

E-mail addresses: radengunawan12@gmail.com (Raden Gunawan Santosa)
} 


\section{Pendahuluan}

Pada era globalisasi seperti saat ini, pendidikan merupakan merupakan hal yang sangat penting dalam menyiapkan generasi yang cerdas, berdaya saing tinggi serta membentuk kepribadian suatu masyarakat. Sekolah merupakan salahsatu lembaga pendidikan formal yang secara tersistematis menyiapkan generasi bangsa ini untuk menghadapi berbagai tantangan perubahan yang akan datang tersebut. Dalam kehidupan sosial, masyarakat cenderung akan selalu berubah, pendidikan memiliki peran dalam merespon perubahan tersebut (Sholeh, 2018).

Kelurahan Seperti kebanyakan siswa SMA di Indonesia, siswa SMA BOPKRI 2 (BODA) juga banyak mengalami kesulitan dalam memahami dan manipulasi simbol terutama dalam Matematika. Salah satu cara menyelesaikan kesulitan ini adalah dengan cara meningkatkan kemampuan berpikir SimbolikMatematik bagi siswa. Berpikir simbolik-matematik adalah teknik berpikir yang mengkombinasikan Logika Simbolik dan Matematika. Dalam logika simbolik, penggunaan simbol bertujuan agar aktivitas berlogika tetap berlandaskan pada "makna tunggal". Dengan acuan "makna tunggal" aktivitas logis seperti ekuivalensi logis dan implikasi logis dapat dilakukan dengan runtun sehingga tetap mempertahankan larangan melakukan kontradiksi . Hal ini juga menjadi landasan bagi sistem di dalam dunia komputer (Huth \& Ryan, 2004) (Ben-Ari, 2012). Logika Simbolik memiliki sebutan lain yaitu Logika Matematika. Walaupun memiliki nama yang mirip, Logika Matematika (Logika Simbolik) dan Matematika membicarakan dua hal yang sangat berbeda. Matematika membicarakan beberapa topik seperti Aljabar, Aritmatika dan Geometri, sedangkan Logika Simbolik membicarakan obyek berupa pernyataanpernyataan dan relasi antar pernyataan tersebut (Smullyan, 2009). Secara khusus Logika Simbolik juga membicarakan sistem yang disebut sistem aksioma.

Walaupun berbeda, Logika Simbolik dan Matematika memiliki hal yang sama yaitu keduanya menggunakan simbol-simbol yang hanya memiliki satu buah makna. Pola berpikir logis kedua bidang ini juga sama. Secara khusus dapat dikatakan pola logis di dalam Logika Simbolik dapat diterapkan pada Matematika. Dengan kata lain, Logika Simbolik dapat diaplikasikan untuk Matematika (Smullyan, 2009).

Pada hakekatnya berpikir matematik adalah sesuatu hal yang penting, dengan alasan sebagai berikut (Stacey, 2005):

1. Berpikir matematika penting sebagai tujuan dari sekolah umum.

2. Berpikir matematik penting sebagai cara belajar matematika.

3. Berpikir matematik penting untuk mengajarkan matematika.

Pemikiran matematika adalah kegiatan yang sangat kompleks, dan yang telah banyak ditulis dan dipelajari oleh para ahli matematika maupun oleh para ahli pendidik. Secara sederhana berpikir matematik memuat dua hal yang sangat penting, yaitu "Specialising and Generalizing" dan "Conjecturing and Convincing". Mason, Burton and Stacey mengidentifikasi empat proses fundamental dalam berpikir matematik (Mason, Burton, \& Stacey, 1982), yaitu :

1. Specialising (mengkhususkan diri) - mencoba kasus khusus, melihat contoh yang lebih sederhana.

2. Generalizing (membuat lebih umum) - mencari pola-pola dan hubungan-hubungan secara lebih luas.

3. Conjecturing (menduga) - memprediksi hubungan-hubungan dan hasil-hasil dari suatu relasi.

4. Convincing (meyakinkan) - menemukan dan mengkomunikasikan alasan mengapa sesuatu hal atau keadaan itu benar.

Pada dasarnya berpikir simbolik-matematik adalah bentuk praktis kombinasi Logika Simbolik dengan fundamental berfikir Matematika. Bentuk praktis berpikir simbolik-matematik adalah berupa teknik-teknik logis dalam menyelesaikan problem Matematika. Secara umum ada tiga aktivitas logika simbolik yang diaplikasikan pada Matematika yaitu membaca simbol, ekuivalensi logis dan implikasi logis (Copi, Cohen, \& McMahon, 2014). Membaca simbol adalah aktivitas menangkap arti simbol. Ekuivalensi logis melakukan penyederhanaan simbol dan implikasi logis melakukan penarikan kesimpulan (Grassmann \& Tremblay, 1996). Teknik berpikir logis yang diaplikasikan pada program ini, adalah :

1. Larangan melakukan kontradiksi.

2. Reduksi Semesta Pembicaraan

3. Penarikan Kesimpulan Universal Generalization.

4. Binary thinking.

5. Informal Reasoning.

6. Konstruksi Logis Berdasarkan Pola

7. Diagram pohon (tree diagram)

8. Diagram Venn

Sedangkan untuk berpikir secara matematik ada 5 asumsi dasar yang penting (Mason, Burton, \& Stacey, 1982), yaitu : 
1. ASUMSI I : Kita dapat berpikir secara matematis

2. ASUMSI 2 : Pemikiran matematika dapat ditingkatkan dengan latihan refleksi

3. ASUMSI 3 : Berpikir secara matematik dapat diprovokasi oleh contradiction (kontradiksi), tension (ketegangan) dan surprise (kejutan)

4. ASUMSI 4 : Berpikir secara matematik didukung oleh suasana mempertanyakan, menantang dan merefleksikan

5. ASUMSI 5 : Berpikir secara matematik membantu dalam memahami diri sendiri dan dunia

Dengan melatihkan teknik berpikir Simbolik-Matematik ini, diharapkan terjadi peningkatan kemampuan logika siswa dalam menghadapi problem Matematika.

Salah satu kemampuan berpikir yang utama dalam Matematika adalah Problem Solving atau Pemecahan Masalah. Problem Solving menjadi penting karena melibatkan cara berpikir yang berbeda untuk pembuatan keputusan. Unsur dalam Problem Solving yaitu berpikir kreatif dan berpikir analitis. Berpikir kreatif memberikan perspektif baru atau menangkap peluang baru dalam bentuk ide-ide baru yang belum pernah ada. Berpikir Analitis adalah berpikir yang menggunakan sebuah tahapan atau langkah-langkah logis. Langkah berpikir analitis ialah dengan menguji sebuah pernyataan atau bukti dengan standar objektif, melihat masalah tidak hanya di permukaan saja tapi sampai dengan akar-akar permasalahan, kemudian menimbang atau memutuskan atas dasar logika. Kedua cara itu tidak saling bertentangan, tetapi saling melengkapi sesuai konteksnya. Sebagai contoh, berpikir kreatif dalam memecahkan sebuah persoalan juga memerlukan cara berpikir analitis untuk memutuskan mana yang terbaik diantara kemungkinan ide-ide baru sebagai hasil yang kreatif.

\section{Metode}

Metode Kegiatan PkM ini akan menghasilkan beberapa output, yaitu :

1. Pembuatan Modul Simbolik-Matematik dari beberapa sumber (Mujiyati, 2015) dan dari tim Pustaka Cerdas $(-, 2016)$

2. Pelatihan Simbolik-Matematik untuk para siswa yang dilakukan sesuai jadwal. Evaluasi dan laporan sebagai bentuk laporan pertanggung-jawaban

Pertama-tama yang dilakukan sebelum melakukan pelatihan bagi para siswa terlebih dahulu dibuat Modul pelatihan Simbolik-Matematik. Modul ini terdiri atas 11 bagian. Bagian-bagian dari modul ini adalah sebagai berikut : bagian yang pertama adalah bagian diagnosis yaitu modul untuk mendiagnosis kemampuan siswa. Sedangkan modul yang lain terdiri dari 10 modul yaitu modul 1 sampai dengan modul 10. Sebagai satu contoh suatu problem yang harus diselesaikan (Wibowo \& Singgih, 2012) adalah :

Seorang ilmuwan melakukan percobaan terhadap 50 ekor kelinci. Dan hasil laporannya sebagai berikut :

1. 25 ekor di antaranya kelinci jantan.

2. 25 ekor dilatih menghindari jebakan, 10 ekor di antaranya jantan.

3. 20 ekor ( dari total 50 ekor) berhasil menghindari jebakan, 4 ekor diantaranya jantan.

4. 15 ekor yang pernah dilatih berhasil menghindari jebakan, 3 ekor di antaranya jantan.

Banyaknya kelinci betina yang tidak pernah dilatih dan tidak dapat menghindari jebakan adalah

Ada dua cara solusi untuk menyelesaikannya Cara 1 Dengan menggunakan logika dalam bahasa formal sebagai berikut :

1. Semuanya ada 50 ekor kelinci.

2. 25 ekor di antara nya adalah kelinci jantan. Berarti , terdapat 25 ekor kelinci betina.

3. 25 ekor dilatih menghindari jebakan, 10 ekor di antaranya jantan. Berarti, terdapat 15 ekor kelinci betina yang dilatih. Ini berarti pula terdapat 10 ekor kelinci betina yang tidak dilatih.

4. 20 ekor ( dari total 50 ekor ) berhasil menghindari jebakan, 4 ekor diantaranya jantan. Berarti ada 16 ekor kelinci betina yang berhasil menghindari jebakan dan ada 9 ekor kelinci betina yang gagal.

5. 15 ekor yang pernah dilatih berhasil menghindari jebakan, 3 ekor diantaranya jantan. Berarti terdapat 12 ekor kelinci betina yang dilatih dan berhasil menghindari jebakan dan ada 3 ekor kelinci betina yang dilatih dan gagal.

Jadi diperoleh informasi bahwa kelinci betina yang tidak dilatih tapi berhasil menghindari jebakan ada sebanyak $16-12=4$. Berarti banyaknya kelinci betina yang tidak dilatih dan tidak dapat menghindari jebakan ada $10-4=6$ ekor.

Cara 2 : Dengan menggunakan pohon atau Tree, lihat gambar ilustrasi dibawah sebagai berikut : 


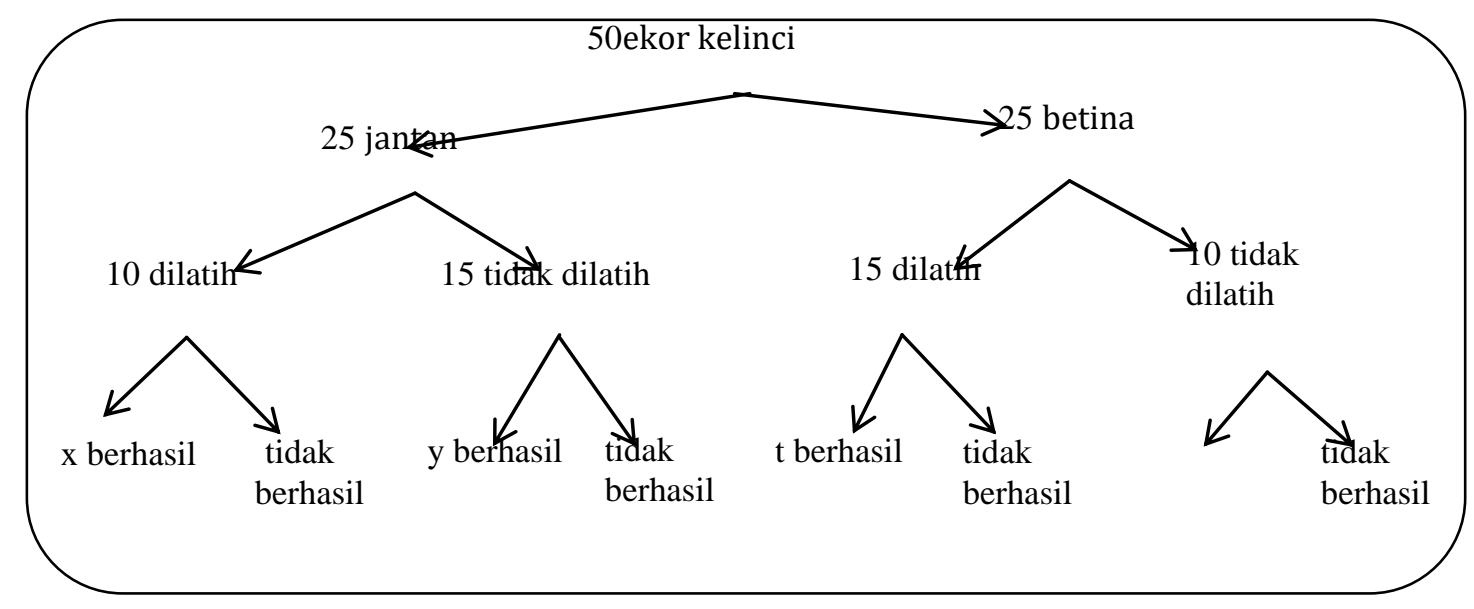

Gambar 1. Ilustrasi Penggunaan Tree

Dari gambar 1 dan dengan menggunakan pemodelan aljabar sederhana, maka didapat:

$\mathrm{x}+\mathrm{y}=4$ (4 ekor jantan yang berhasil menghindari jebakan)

$\mathrm{t}+\mathrm{z}=16$ (karena total yang berhasil adalah 20)

$\mathrm{t}=12$ (12 ekor betina yang dilatih dan berhasil menghindari jebakan)

Sehingga $\mathrm{z}=4$. Dengan demikian kelinci betina yang tidak pernah dilatih dan tidak dapat menghindari jebakan adalah : $10-4=6$ ekor.

Pelajaran matematika di Jepang, terutama untuk kelas dasar, sebagian besar menggunakan metode Problem-Solving (pemecahan masalah). Takahashi (2006) menggunakan pendekatan Problem-Solving ini, yang disebut penyelesaian masalah terstruktur, metode ini dirancang untuk menciptakan minat dalam pelajaran matematika dan merangsang aktivitas kreatif di kelas melalui kerja kolaboratif para siswa.

Pelajaran matematika di sana biasanya dimulai dengan siswa yang bekerja secara individu untuk memecahkan masalah yang diberikan oleh guru dengan menggunakan pengetahuan matematika mereka sendiri. Setelah bekerja dengan masalah tersebut, siswa membawa berbagai pendekatan dan solusi untuk diskusi kelas. Guru kemudian memimpin siswa dalam diskusi seluruh kelas untuk membandingkan pendekatan penyelesaian masalah dan solusi setiap individu. Kegiatan di kelas ini memberikan siswa dengan kesempatan untuk mengembangkan kemampuan matematika mereka termasuk pemahaman konseptual dan prosedural (Takahashi, 2006).

Metode Pelatihan Simbolik-Matematik bagi para siswa SMA BODA mengadopsi dan memodifikasi dari metode Takashi tersebut . Metode ini terdiri dari beberapa tahapan sebagai berikut :

1. Mendiagnosis permasalahan siswa dalam melakukan aktvitas logika simbolik dengan cara siswa diberikan problem diagnosis untuk dikerjakan. Kemudian setelah hasil pengerjaan siswa dikumpulkan, maka intrukttur dan siswa bersama-sama mendiskusikan cara menyelesaikan masalah tersebut.

2. Membagikan modul yang berbeda- beda sesuai dengan jadwal pelatihan.

3. Membahas dan mendiskusikan cara penyelesaikan problem dalam modul yang telah dibagikan tersebut.

4. Menyimpulkan cara menyelesaikan problem dalam pertemuan pada hari itu juga. Kesimpulan tersebut diperoleh dengan membagikan kuisioner tentang cara atau strategi yang digunakan untuk menyelesaikan problem tersebut. Dan siswa boleh memilih cara (strategi) yang digunakan untuk menyelesaikan problem. Untuk jawabannya, siswa boleh memilih lebih dari satu macam strategi. Ada lima belas strategi yang digunakan dalam pelatihan Simbolik-Matematik, yaitu :

a. Guess and check (tebak dan periksa) $\rightarrow$ strategi 1

b. Make an organized list (membuat daftar terorganisir) $\rightarrow$ strategi 2

c. Eliminate possibilities (menghilangkan kemungkinan) $\rightarrow$ strategi 3

d. Use symmetry (gunakan simetri) $\rightarrow$ strategi 4

e. Consider special cases (mempertimbangkan kasus khusus) $\rightarrow$ strategi 5

f. Use direct reasoning (gunakan penalaran langsung) $\rightarrow$ strategi 6

g. Solving equation (memecahkan persamaan) $\rightarrow$ strategi 7

h. Look for a pattern (cari polanya) $\rightarrow$ strategi 8

i. Draw a picture (menggambar) $\rightarrow$ strategi 9

j. Solve a simpler problem (memecahkan masalah yang lebih sederhana) $\rightarrow$ strategi 10

k. Use a model (gunakan model) $\rightarrow$ strategi 11

l. Work backward (bekerjalah mundur) $\rightarrow$ strategi 12

$\mathrm{m}$. Use a formula (gunakan formula/rumus) $\rightarrow$ strategi 13 
n. $\quad$ Be ingenious (cerdik) $\rightarrow$ strategi 14

o. Consider extremes (pertimbangkan ekstrem) $\rightarrow$ strategi 15

Siswa diberi tugas untuk membuat kesimpulan berdasarkan cara menyelesaikan problem solving tersebut dari 15 strategi yang ada . Lima belas strategi tersebut merupakan "nama" yang diberikan sesuai dengan diskusi dan proses cara menyelesaikan pada tahap 3.

Adapun jadwal kegiatan yang akan dilaksanakan adalah sekitar awal bulan Juli, akan tetapi berhubung ada beberapa pertimbangan faktor maka kegiatan tersebut diundur sampai dengan awal Agustus . Jadwal pelatihan yang akan diadakan adalah seperti pada Tabel 1.

Tabel 1. Jadwal Pelatihan Simbolik-Matematik SMA BOPKRI 2

\begin{tabular}{|c|c|c|c|c|}
\hline No & Tanggal Pertemuan & Waktu & Materi & Instruktur \\
\hline 1 & $\begin{array}{l}\text { Pertemuan } 1 \\
9 \text { Agustus } 2019\end{array}$ & $\begin{array}{l}\text { Jumat } \\
13.00-15.00\end{array}$ & $\begin{array}{l}\text { Diagnosis (untuk siswa } \\
\text { kelas XII) }\end{array}$ & $\begin{array}{l}\text { Junius Karel Tampubolon } \\
\text { R. Gunawan Santosa }\end{array}$ \\
\hline 2 & $\begin{array}{l}\text { Pertemuan } 2 \\
23 \text { Agustus } 2019\end{array}$ & $\begin{array}{l}\text { Jumat } \\
13.00-15.00\end{array}$ & Modul 1 & $\begin{array}{l}\text { R. Gunawan Santosa } \\
\text { Junius Karel Tampubolon }\end{array}$ \\
\hline 3 & $\begin{array}{l}\text { Pertemuan } 3 \\
06 \text { September } 2019\end{array}$ & $\begin{array}{l}\text { Jumat } \\
13.00-15.00\end{array}$ & Modul 2 & $\begin{array}{l}\text { Junius Karel Tampubolon } \\
\text { R. Gunawan Santosa }\end{array}$ \\
\hline 4 & $\begin{array}{l}\text { Pertemuan } 4 \\
04 \text { Oktober } 2019\end{array}$ & $\begin{array}{l}\text { Jumat } \\
13.00-15.00\end{array}$ & Modul 3 & $\begin{array}{l}\text { R. Gunawan Santosa } \\
\text { Junius Karel Tampubolon }\end{array}$ \\
\hline 5 & $\begin{array}{l}\text { Pertemuan } 4 \\
08 \text { Oktober } 2019\end{array}$ & $\begin{array}{l}\text { Selasa } \\
11.00-12.00\end{array}$ & $\begin{array}{l}\text { Diagnosis (untuk siswa } \\
\text { kelas X) }\end{array}$ & $\begin{array}{l}\text { R. Gunawan Santosa } \\
\text { Junius Karel Tampubolon }\end{array}$ \\
\hline 6 & $\begin{array}{l}\text { Pertemuan } 5 \\
11 \text { Oktober } 2019\end{array}$ & $\begin{array}{l}\text { Jumat } \\
08.00-09.00\end{array}$ & Modul 1 & $\begin{array}{l}\text { Junius Karel Tampubolon } \\
\text { R. Gunawan Santosa }\end{array}$ \\
\hline 7 & $\begin{array}{l}\text { Pertemuan } 6 \\
18 \text { Oktober } 2019\end{array}$ & $\begin{array}{l}\text { Jumat } \\
08.00-09.00\end{array}$ & Modul 2 & $\begin{array}{l}\text { R. Gunawan Santosa } \\
\text { Junius Karel Tampubolon }\end{array}$ \\
\hline 8 & $\begin{array}{l}\text { Pertemuan } 7 \\
22 \text { Oktober } 2019\end{array}$ & $\begin{array}{l}\text { Selasa } \\
11.00-12.00\end{array}$ & Modul 3 & $\begin{array}{l}\text { Junius Karel Tampubolon } \\
\text { R. Gunawan Santosa }\end{array}$ \\
\hline 9 & $\begin{array}{l}\text { Pertemuan } 8 \\
25 \text { Oktober } 2019\end{array}$ & $\begin{array}{l}\text { Jumat } \\
08.00-09.00\end{array}$ & Modul 4 & $\begin{array}{l}\text { R. Gunawan Santosa } \\
\text { Junius Karel Tampubolon }\end{array}$ \\
\hline 10 & $\begin{array}{l}\text { Pertemuan } 9 \\
01 \text { November } 2019\end{array}$ & $\begin{array}{l}\text { Jumat } \\
13.00-15.00\end{array}$ & Modul 5 & $\begin{array}{l}\text { Junius Karel Tampubolon } \\
\text { R. Gunawan Santosa }\end{array}$ \\
\hline 11 & $\begin{array}{l}\text { Pertemuan } 11 \\
08 \text { November } 2019\end{array}$ & $\begin{array}{l}\text { Jumat } \\
13.00-15.00\end{array}$ & Modul 6 & $\begin{array}{l}\text { R. Gunawan Santosa } \\
\text { Junius Karel Tampubolon }\end{array}$ \\
\hline
\end{tabular}

Waktu pelatihan sangat fleksibel karena banyaknya kegiatan siswa SMA BODA saat ini, tetapi waktu pelatihan tersebut dapat dipenuhi sesuai dengan yang direncanakan yaitu sebanyak 11 kali pertemuan ( 4 kali pertemuan dengan kelas XII dan 7 kali pertemuan dengan kelas X) Kegiatan suasana pelatihan yang terjadi di kelas dapat dilihat pada gambar 2 .

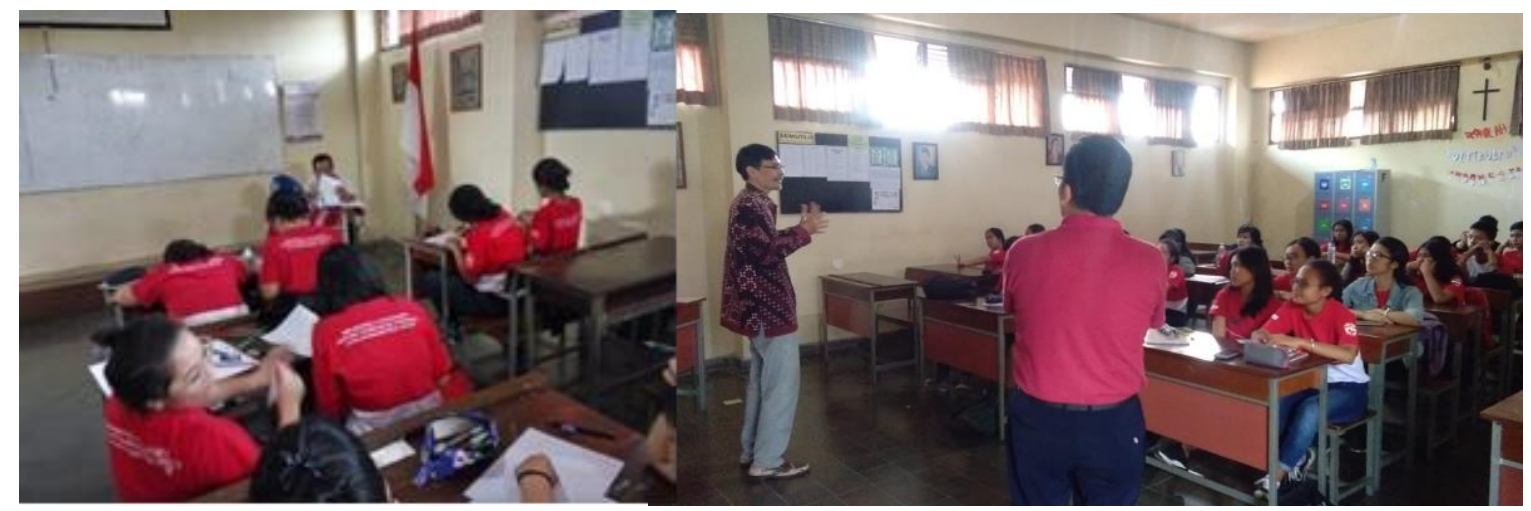

Gambar 2. Gambaran Suasana Pelatihan 


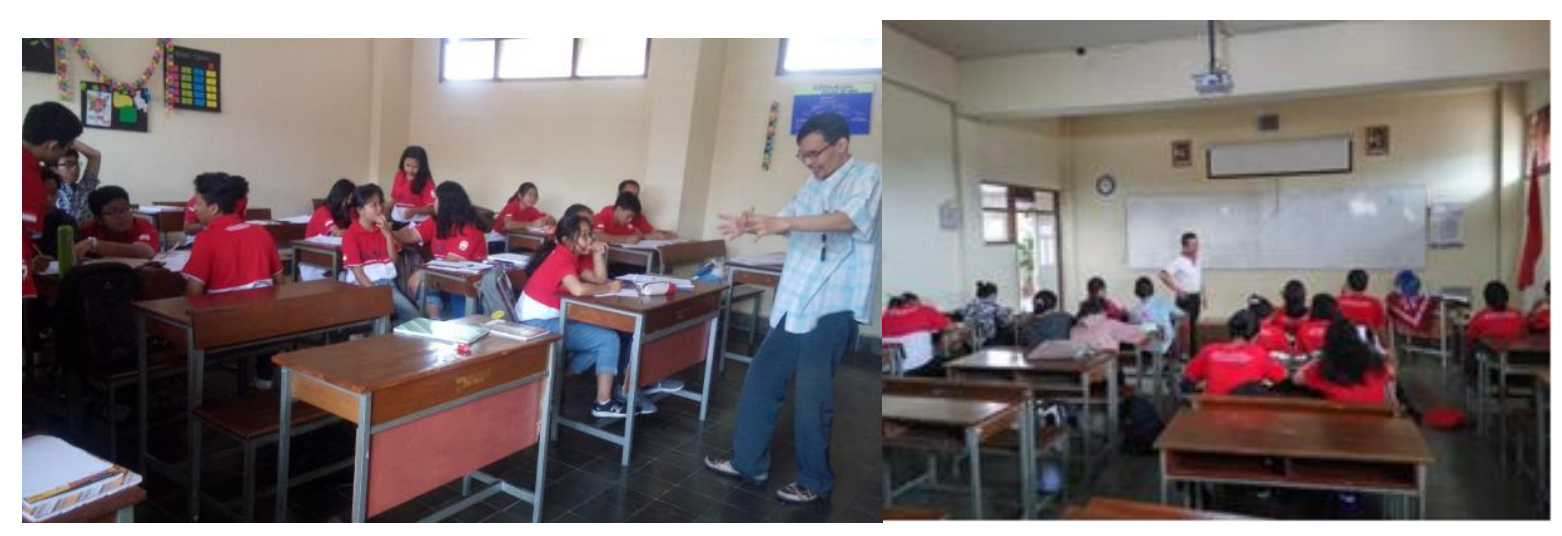

Gambar 3. Gambaran Diskusi yang Terjadi di Kelas

Pada gambar 3 terlihat suasana diskusi dalam kelas yaitu diskusi yang terjadi antara siswa dengan siswa ataupun diskusi antara siswa dan pengajar.

Bagian akhir dari kegiatan Pengabdian masyarakat ini adalah evaluasi dan laporan akhir. Evaluasi dilakukan pada setiap akhir pelatihan tapi selain itu evaluasi juga diadakan pada akhir periode pengabdian sebelum pembuatan laporan akhir. Selain laporan akhir, pada pengabdian ini juga dihasilkan Modul Pelatihan Simbolik-Matematik

\section{Hasil dan pembahasan}

Hasil dari kemampuan siswa dalam mengikuti pelatihan Simbolik -Matematik dapat dilihat pada Tabel 2 dan Tabel 3. Untuk menjaga privasi siswa maka nama siswa diganti dengan kode Siswa 1 samapai dengan Siswa 34.

Tabel 2 . Hasil Cara Berpikir Dalam Penyelesaian Modul Pada Siswa Kelas XII BODA

\begin{tabular}{|c|c|c|c|c|c|}
\hline \multirow[b]{2}{*}{ No } & \multirow[b]{2}{*}{ Nama } & \multicolumn{4}{|c|}{ Modul } \\
\hline & & Diagnosa & Modul 1 & Modul 2 & Modul3 \\
\hline 1 & Siswa 1 & kurang & & & \\
\hline 2 & Siswa 2 & cukup & cukup baik & kurang & kurang \\
\hline 3 & Siswa 3 & cukup & & & \\
\hline 4 & Siswa 4 & cukup & Kurang & & \\
\hline 5 & Siswa 5 & cukup & & & \\
\hline 6 & Siswa 6 & cukup & Kurang & kurang & \\
\hline 7 & Siswa 7 & cukup baik & Cukup & kurang & \\
\hline 8 & Siswa 8 & kurang & & kurang & kurang \\
\hline 9 & Siswa 9 & kurang & & kurang & kurang \\
\hline 10 & Siswa 10 & cukup & & kurang & cukup \\
\hline 11 & Siswa 11 & cukup & & kurang & kurang \\
\hline 12 & Siswa 12 & cukup & & & \\
\hline 13 & Siswa 13 & cukup & & & \\
\hline 14 & Siswa 14 & cukup & & & \\
\hline 15 & Siswa 15 & cukup & & & \\
\hline 16 & Siswa 16 & cukup baik & Kurang & & \\
\hline 17 & Siswa 17 & cukup & Cukup & & \\
\hline 18 & Siswa 18 & cukup & Kurang & & \\
\hline 19 & Siswa 19 & cukup & Cukup & kurang & \\
\hline 20 & Siswa 20 & cukup & Kurang & kurang & \\
\hline 21 & Siswa 21 & cukup & Kurang & kurang & \\
\hline 22 & Siswa 22 & & Kurang & & cukup \\
\hline 23 & Siswa 23 & & Kurang & & \\
\hline 24 & Siswa 24 & & Cukup & & kurang \\
\hline 25 & Siswa 25 & & Cukup & & \\
\hline 26 & Siswa 26 & & & & kurang \\
\hline 27 & Siswa 27 & & & & kurang \\
\hline
\end{tabular}




\begin{tabular}{|c|c|c|c|c|c|}
\hline \multirow[b]{2}{*}{ No } & \multirow[b]{2}{*}{ Nama } & \multicolumn{4}{|c|}{ Modul } \\
\hline & & Diagnosa & Modul 1 & Modul 2 & Modul3 \\
\hline 28 & Siswa 28 & & & & kurang \\
\hline 29 & Siswa 29 & & & & cukup \\
\hline 30 & Siswa 30 & & & & kurang \\
\hline 31 & Siswa 31 & & & & kurang \\
\hline 32 & Siswa 32 & & & & kurang \\
\hline 33 & Siswa 33 & & & & kurang \\
\hline 34 & Siswa 34 & & & & kurang \\
\hline & kurang & 3 & 8 & 10 & 13 \\
\hline & cukup & 16 & 5 & 0 & 3 \\
\hline & cukup baik & 2 & 0 & 0 & 0 \\
\hline & Jumlah & 21 & 13 & 10 & 16 \\
\hline
\end{tabular}

Dari Tabel 2 terlihat bahwa jumlah siswa mempunyai kriteria "kurang" adalah semakin banyak karena banyaknya siswa yang mengikuti kegiatan pelatihan ini tidak kontinu. Ketidak kontinuan ini disebabkan adanya banyak kegiatan yang dilakukan oleh para siswa. Dari tabel tersebut juga terlihat bahwa banyak siswa yang tidak masuk (absen) pada pelatihan untuk siswa kelas XII di BODA. Siswa 26 sampai dengan Siswa 34 tidak mengikuti pelatihan di Modul Diagnosa, Modul 1 dan Modul 2 , sehingga mereka langsung mengikuti modul 3.

Tabel 3 . Hasil Cara Berpikir Dalam Penyelesaian Modul Pada Siswa Kelas X BODA

\begin{tabular}{|c|c|c|c|c|c|c|c|c|}
\hline No & Nama & Diagnosa & Modul 1 & Modul 2 & $\begin{array}{l}\text { Modul } \\
\text { Modul } 3\end{array}$ & Modul 4 & Modul 5 & Modul 6 \\
\hline 1 & Siswa 1 & kurang & kurang & kurang & cukup & cukup & cukup & kurang \\
\hline 2 & Siswa 2 & & kurang & kurang & kurang & kurang & cukup & cukup \\
\hline 3 & Siswa 3 & & kurang & kurang & kurang & kurang & kurang & kurang \\
\hline 4 & Siswa 4 & kurang & kurang & kurang & kurang & & cukup & cukup \\
\hline 5 & Siswa 5 & kurang & cukup & kurang & & kurang & cukup & kurang \\
\hline 6 & Siswa 6 & kurang & kurang & kurang & kurang & & cukup & kurang \\
\hline 7 & Siswa 7 & kurang & kurang & kurang & cukup & kurang & cukup & cukup \\
\hline 8 & Siswa 8 & kurang & & kurang & & & & \\
\hline 9 & Siswa 9 & kurang & & kurang & kurang & cukup & cukup & bagus \\
\hline 10 & Siswa 10 & kurang & kurang & & & & & \\
\hline 11 & Siswa 11 & kurang & cukup & kurang & kurang & kurang & kurang & kurang \\
\hline 12 & Siswa 12 & kurang & kurang & & & & & kurang \\
\hline 13 & Siswa 13 & kurang & & kurang & cukup & kurang & cukup & cukup \\
\hline 14 & Siswa 14 & kurang & kurang & kurang & kurang & kurang & cukup & cukup \\
\hline 15 & Siswa 15 & kurang & & & & & cukup & bagus \\
\hline 16 & Siswa 16 & kurang & kurang & kurang & kurang & & & \\
\hline 17 & Siswa 17 & cukup & kurang & kurang & cukup & kurang & cukup & cukup \\
\hline 18 & Siswa 18 & cukup & kurang & kurang & kurang & kurang & kurang & cukup \\
\hline 19 & Siswa 19 & cukup & kurang & kurang & kurang & kurang & cukup & kurang \\
\hline 20 & Siswa 20 & kurang & kurang & kurang & kurang & kurang & cukup & kurang \\
\hline 21 & Siswa 21 & kurang & & cukup & kurang & kurang & cukup & bagus \\
\hline 22 & Siswa 22 & kurang & kurang & & kurang & kurang & cukup & cukup \\
\hline 23 & Siswa 23 & & & kurang & kurang & kurang & & \\
\hline 24 & Siswa 24 & kurang & & kurang & & kurang & kurang & cukup \\
\hline 25 & Siswa 25 & kurang & kurang & kurang & cukup & kurang & kurang & cukup \\
\hline & kurang & 19 & 16 & 20 & 14 & 16 & 5 & 8 \\
\hline & cukup & 3 & 2 & 1 & 4 & 1 & 14 & 10 \\
\hline & bagus & 0 & 0 & 0 & 0 & 0 & 0 & 3 \\
\hline
\end{tabular}


Dari Tabel 3 terlihat bahwa jumlah siswa mempunyai kriteria "kurang" adalah semakin banyak pada Modul Diagnosa, Modul 1 sd Modul 4. Dari tabel tersebut juga terlihat bahwa banyak siswa yang mempunyai kriteria "cukup" semakin banyak untuk Modul 5 dan Modul 6. Hal ini terjadi karena perbedaan jenis isi Modul. Dari tabel di atas juga terlihat bahwa siswa kelas X BODA lebih kontinu dalam mengikuti kegiatan ini.

Biasanya keberhasilan program pelatihan diukur dengan menggunakan perbandingan nilai Pre-tes dan Post-tes, seperti dilakukan oleh Behlol , Akbar dan Sehrish (2018) . Mereka melakukan penelitian untuk menyelidiki efektivitas Problem-Solving Approach (PSA) atau Pendekatan Pemecahan Masalah dalam pengajaran matematika untuk siswa kelas 8 di sekolah umum. Desain kesamaan kelompok Pre-test dan Post-test digunakan untuk melakukan penelitian ini. Peneliti ini menerapkan teknik matching (pencocokan) untuk menempatkan siswa dalam kelompok eksperimen dan kelompok kontrol (Control Group). Tes prestasi digunakan sebagai Pre-test dan Post-test dalam penelitian ini. Penelitian ini mengungkapkan bahwa tingkat pencapaian siswa yang diajarkan melalui PSA berbeda secara signifikan dibandingkan dengan kinerja siswa yang diajarkan melalui metode pengajaran tradisional pada nilai Posttest (Behlol, Akbar, \& Sehrish, 2018). Dengan selesaianya pengabdian pada masyarakat ini dan karena adanya ke tidak kontinuan para siswa dalam mengikuti kegiatan pelatihan lewat modul modul yang ada, maka ukuran keberhasilan pelatihan ini digunakan metode secara deskriptif saja.

Untuk sementara dapat disimpulkan bahwa pelaksanaan program pengabdian masyarakat ini masih berjalan sesuai dengan jadwal yang direncanakan. Tapi pelatihan yang dilaksanakan tidak bisa sampai Modul 10. Modul yang berhasil dijalankan hanya sampai dengan Modul 6 karena keterbatasan waktu. Ada empat jenis berpikir simbolik matematik yang dilatihkan yaitu : penalaran langsung, penggunaan model pada sebuah sistem, melihat pola dan penarikan kesimpulan yang mengacu pada definisi matematika yang baku.

Tabel 4 . Klasifikasi Jenis Berpikir yang Dituangkan dalam Bentuk Modul Pelatihan

\begin{tabular}{ll}
\hline Jenis Berpikir Simbolik Matematik (Strategi) & \multicolumn{1}{c}{ Problem yang diberikan pada Modul } \\
Penalaran langsung & Modul diagnosa problem 1; modul 5 problem 1,2; \\
& modul 6 problem 1 \\
Penggunaan model pada sebuah sistem & Modul diagnosa problem 2; modul 1 problem \\
& 1;modul 2 problem 1,2. \\
Melihat pola & Modul diagnosa problem 3; modul 1 problem \\
& $2 ;$ modul 2 problem 3 \\
Penarikan kesimpulan yang mengacu pada & Modul diagnosa problem 4;modul 3 problem \\
definisi matematika yang baku & $1,2,3,4 ;$ modul 4 problem 1,2,3,4. \\
\hline
\end{tabular}

Dari lembar jawaban dan pengamatan langsung, dapat disimpulkan bahwa para siswa cenderung lebih mudah menyelesaikan problem dengan jenis penalaran langsung. Problem jenis ini diberikan dalam bentuk kata-kata untuk kasus yang biasa mereka hadapi sehari-hari. Hal ini tampak pada hasil diagnosa kelompok kelas XII ( Tabel 2) dan hasil modul 5 dan modul 6 kelompok kelas X ( Tabel 3) . Untuk kelas X, hasil diagnosa memang menunjukkan hasil kurang, namun untuk problem jenis yang sama selanjutnya (modul 5 dan 6), kelompok ini menunjukkan jenis problem ini lebih mudah mereka hadapi dan selesaikan dibandingkan jenis problem lainnya. Jenis yang paling sulit dihadapi para siswa adalah jenis problem yang memerlukan penarikan kesimpulan yang mengacu pada definisi matematika yang baku. Untuk jenis penggunaan strategi penyelesaian model pada sebuah sistem dan jenis melihat pola, para siswa cenderung dapat menyelesaikan soal setelah diberi petunjuk bagaimana model yang cocok pada problem serta pola yang dimiliki problem.

\section{Simpulan dan saran}

Beberapa kesimpulan yang didapat dari kegiatan pengabdian pada masyarakat ini adalah sebagai berikut :

1. Pembuatan modul dan pelatihan ini dapat dilaksanakan dengan baik meskipun waktunya sangat mepet. Waktu pelatihan sangat fleksibel karena banyaknya kegiatan siswa SMA BODA saat ini, tetapi waktu pelatihan tersebut dapat dipenuhi sesuai dengan yang direncanakan yaitu sebanyak 11 pertemuan ( 4 kali pertemuan dengan kelas XII dan 7 kali pertemuan dengan kelas X) 
2. Adanya dukungan dari pihak SMA BODA terutama dalam memberi fasilitas berupa penyediaan waktu sehingga acara ini dapat berlangsung. Kegiatan ini juga merangsang daya pikir siswa, sehingga secara tidak sadar mereka dapat menerapkan cara berpikir problem solving.

3. Jenis yang paling sulit dihadapi para siswa adalah jenis problem yang memerlukan penarikan kesimpulan yang mengacu pada definisi matematika yang baku.

4. Untuk jenis penggunaan strategi penyelesaian model pada sebuah sistem dan jenis melihat pola, para siswa cenderung dapat menyelesaikan soal setelah diberi petunjuk bagaimana model yang cocok pada problem serta pola yang dimiliki problem.

5. Dapat dilihat dari dua kelompok kelas siswa bahwa kelas yang kontinu mengikuti pelatihan lebih mendapatkan peningkatan kemampuan berpikir simbolik-matematik.

6. Dalam kegiatan pengabdian pada masyarakat dibutuhkan kerjasama dan sistem yang lebih fleksibel lagi berhubungan dengan jadwal masing-masing organisasi yang sangat padat.

\section{Daftar Rujukan}

Behlol, M. G., Akbar, R. A., \& Sehrish, H. (2018, April). Effectiveness of Problem Solving Method in Teaching Mathematics at Elementary Level . Bulletin of Education Research Vol. 40 No. 1, pp. 231-244.

Ben-Ari, M. (2012). Mathematical Logic for Computer Science third Edition. London: Springer-Verlag.

Copi, I. M., Cohen, C., \& McMahon, K. (2014). Introduction to Logic Fourteenth Edition. Pearson New International Edition.

Grassmann, W. K., \& Tremblay, J. P. (1996). Logic and Discrete Mathematics, A Computer Science Perspective. New Jersey : Prentice Hall.

Huth, M., \& Ryan, M. (2004). Logic in Computer Science, Modelling and Reasoning about System. Cambridge University Press.

Mason, J., Burton, L., \& Stacey, K. (1982). Thinking Mathematically. Addison-Wesley Publishing Company.

Mujiyati. (2015). Siap Jadi Juara Nasional Matematika SMA. Pustaka Baru Press.

Sholeh, Badrus. 2018. Pengaruh Motivasi Belajar Dan Fasilitas Belajar Terhadap Prestasi Belajar Ips Siswa Smp Nurul Iman Parung Bogor Tahun Ajaran 2017/2018 . Jurnal Pendidikan, Ekonomi dan Bisnis Vol 3 No 2 Oktober 2018.

Smullyan, R. M. (2009). Logical Labyrinths. Wellesley, Massachusetts : A K Peters, Ltd.

Stacey, K. (2005). The Place of Problem Solving in Contemporary Mathematics Curriculum Documents. The Journal of Mathematicsal Behavior 24 (3-4) , 341-350.

Takahashi, A. (2006). Characteristics of Japanese Mathematics Lessons. Tsukuba Journal of Educational Study in Mathematics Vol. 25 .

Wibowo, \& Singgih, S. (2012). Menyongsong OSN Matematika SMP. Pustaka Pelajar. 